\title{
Analisis Kelayakan Aspek Teknis Produksi Pembuatan Pakan Ternak Dari Sampah Organik Dapur di PPM BSF Dadali Kalibaru Bekasi Jawa Barat
}

\author{
Intan Permata Dewi ${ }^{1 *}$, Muhammad Rizal Taufikurohman', Noverdi Bross² \\ ${ }^{1}$ Departemen Agribisnis, Fakultas Bioindustri, Universitas Trilogi \\ ${ }^{2}$ Departemen Manajemen, Fakultas Ekonomi dan Bisnis, Universitas Trilogi \\ *Corresponding author: intanpd98@gmail.com
}

\begin{abstract}
Abstrak
Pembudidayaan maggot bsf adalah kegiatan di mana seseorang melakukan pemeliharaan terhadap maggot mulai dari perawatan telur, pembesaran maggot, penetasan pre-pupa menjadi lalat, hingga pemberian pakan unggas menggunakan maggot. Tujuan dari penelitian ini adalah: Menganalisis kelayakan usaha pembudidayaan maggot bsf berdasarkan aspek teknis produksi. Data yang digunakan pada penelitian ini merupakan data primer dan data sekunder, di mana data primer diperoleh melalui hasil wawancara pada pelaku usaha dan observasi. Data sekunder diperoleh melalui literatur, jurnal, penelitian terdahulu dan juga buku yang terkait dengan teori tentang penelitian yang dilakukan. Data dan informasi yang telah dikumpulkan dianalisis secara kuantitatif yang diolah menggunakan Microsoft Word 2013. Hasil penelitian yang dilakukan yaitu: Pembudidayaan maggot yang dilakukan layak untuk dijalankan karena menimbang dari pemilihan lokasi yang dekat dengan penampungan sampah yang terletak di Kali Baru, Medan Satria, Kota Bekasi yang di mana sampah organik menjadi bahan baku utamanya. Tempat pembudidayaan juga tersedia tenaga listrik dan air untuk penunjang kebutuhan produksi. Tenaga kerja dan fasilitas transportasi juga sangat mendukung untuk menunjang produksi dan pendistribusian hasil produksi. Maka dari itu, usaha pembudidayaan maggot yang dijalankan oleh PPM BSF Dadali ini dikatakan layak. Rekomendasi yang diberikan adalah pelaku usaha dapat mengembangkan usaha yang dijalankan dengan memperluas lahan yang akan digunakan, guna meningkatkan kuantitas produksi maggot.
\end{abstract}

Kata kunci: Studi kelayakan, Aspek teknis produksi

\begin{abstract}
BSF maggot cultivation is an activity where someone maintains maggot starting from egg care, maggot enlargement, hatching of pre-pupa into flies, to feeding poultry using maggot. The objectives of this study are: To analyze the feasibility of the BSF maggot cultivation business based on the technical aspects of production. The data used in this study are primary data and secondary data, where primary data is obtained through interviews with business actors and observations. Secondary data is obtained through literature, journals, previous research, and also books related to the theory of research being carried out. The data and information collected were analyzed quantitatively and processed using Microsoft Word 2013. The results of the research carried out were: Maggot cultivation was feasible to run because considering the selection of a location close to a garbage collection located in Kali Baru, Medan Satria, Bekasi City. Where organic waste is the main raw material. The place for cultivation is also provided with electricity and water to support production needs. Labor and transportation facilities are also very supportive to support the production and distribution of production products. Therefore, the maggot cultivation business carried out by PPM BSF Dadali is said to be feasible. The recommendation given is that business actors can develop a business that is run by expanding the land to be used, to increase the quantity of maggot production.
\end{abstract}

Keywords: Feasibility study, Technical production aspect. 
Prosiding Seminar Nasional Pembangunan dan Pendidikan Vokasi Pertanian

Politeknik Pembangunan Pertanian Manokwari, 14 November 2020

e ISSN : 2774-1982

\section{PENDAHULUAN}

Timbulan sampah di dunia sudah tidak dapat ditangani secara maksimal karena keterbatasan kemampuan dan juga kurangnya peralatan penunjang yang optimal untuk mengurangi timbulan yang sudah sangat banyak. Menurut KLHK (2017) penimbulan sampah di Indonesia tahun 2016 mencapai 65.200 .000 ton pertahunnya dengan penduduk sebesar 261.115.456 jiwa. Jumlah penduduk Indonesia yang terus bertambah menyebabkan bertambah banyaknya juga timbulan sampah yang dihasilkan. Maka dari itu, harus dilakukan sebuah upaya agar target Sustainable Development Goals (SDGs) senilai 12.5 yang menyatakan bahwa sebuah Negara dengan substansial mengurangi banyaknya timbulan sampah melalui langkah pencegahan, pengurangan, daur ulang dan penggunaan kembali dapat tercapai. Pada 2019, Kementerian Lingkungan Hidup dan Kehutanan (KLHK) mengemukakan bahwa jumlah timbulan sampah dihitung secara nasional mencapai angka sebesar 175.000 ton per hari atau setara dengan 64 juta ton per tahun jika asumsi sampah yang dihasilkan setiap orang per hari sebesar $0,7 \mathrm{~kg}$. Limbah yang dihasilkan oleh rumah makan memang menjadi hal yang tidak dapat dihindarkan lagi khususnya sampah organik dapur. Menurut KLHK (2017), sampah organik dapur setidaknya menyumbang $60 \%$ dari muatan truk sampah yang nantinya akan ditujukan ke TPA (Tempat Pembuangan Akhir).

Menurut Tiara Aliya Azzahra (2020) hasil wawancara dengan Menteri Lingkungan Hidup, Ibu Siti Nurbaya menaksir timbunan sampah di Indonesia pada tahun 2020 sebesar 67.8 juta ton dan adanya kemungkinan akan terus bertambah. Makan adalah salah satu kegiatan yang bertujuan untuk memenuhi kebutuhan manusia agar dapat melakukan aktivitas sehari-hari. Beragam jenis makanan yang ada di Indonesia, membuat manusia memiliki berbagai macam pilihan untuk mengonsumsi makanan setiap harinya yang tentunya bisa menimbulkan banyak sampah di Ibu Kota karena pengelolaan sebelum makanan tersebut jadi, pasti ada sisa-sisa sayur atau bahan makanan yang terbuang. Menurut Sistem Informasi Pengelolaan Sampah Nasional (2018), pada periode 2017-2018 jumlah timbulan sampah harian Ibu Kota di Jawa Barat khususnya Kota Bekasi dapat mencapai 1.224 ton/hari. 
Prosiding Seminar Nasional Pembangunan dan Pendidikan Vokasi Pertanian Politeknik Pembangunan Pertanian Manokwari, 14 November 2020

e ISSN : 2774-1982

Tabel 1. Jumlah Timbulan Sampah di Kabupaten dan Kota Bekasi Tahun 2019

\begin{tabular}{|c|c|c|c|c|c|}
\hline $\begin{array}{c}\text { Kabupaten/ } \\
\text { Kota }\end{array}$ & $\begin{array}{c}\text { Jumlah } \\
\text { Penduduk }\end{array}$ & $\begin{array}{c}\text { Jumlah Timbulan } \\
\text { Sampah per- } \\
\text { orang/Hari } \\
\text { (Liter/Orang/Hari) }\end{array}$ & $\begin{array}{c}\text { Total } \\
\text { Sampah } \\
\text { Per-Hari } \\
\text { (liter) }\end{array}$ & $\begin{array}{c}\text { Total } \\
\text { Sampah } \\
\text { dalam satu } \\
\text { tahun } \\
\text { (Liter) }\end{array}$ & $\begin{array}{c}\text { Total } \\
\text { sampah } \\
\text { dalam } \\
\text { satu tahun } \\
\text { (ton) }\end{array}$ \\
\hline $\begin{array}{l}\text { Kabupaten } \\
\text { Bekasi }\end{array}$ & $2,482,751$ & 3 & $7,448,253$ & $\begin{array}{c}2,718,612,3 \\
45\end{array}$ & $\begin{array}{c}2,718,612 . \\
35\end{array}$ \\
\hline Kota Bekasi & $2,381,053$ & 2.41 & $5,738,338$ & $\begin{array}{c}2,094,493,2 \\
71\end{array}$ & $\begin{array}{c}2,094,493 . \\
27\end{array}$ \\
\hline
\end{tabular}

Sumber : Cipta Karya, 2019.

Tabel 1 menunjukkan bahwa persampahan di Kabupaten Bekasi per-harinya menghasilkan sekitar 7,448,253 liter, sedangkan di Kota Bekasi per-harinya menghasilkan sekitar 5,738,338 liter. Salah satu cara mengurangi timbulan sampah menurut Peraturan Menteri No 13 Tahun 2012 adalah melalui Bank Sampah dan sampah organik dapur diolah menjadi kompos, namun belum sepenuhnya menangani masalah sampah organik dapur tersebut.

Kewirausahaan adalah salah satu profesi yang memiliki peran penting sebagai penggerak perekonomian suatu Negara, karena kewirausahaan merupakan sektor yang dapat menyerap tenaga kerja lebih banyak dibandingkan dengan sektor lainnya. Pada tahun 2018, rasio kewirausahaan di Indonesia telah mencapai 7 persen dari total penduduk Indonesia (Media Indonesia, 2018). Usaha pembudidayaan maggot ini dapat dikatakan sebagai salah satu sekotor kewirausahaan yang mampu menyerap tenaga kerja dan tidak membutuhkan pendidikan yang tinggi, maka dari itu usaha budidaya maggot ini membuka peluang lapangan kerja bagi orang-orang yang putus sekolah. Mengingat maggot adalah sumber protein yang tinggi untuk diberikan kepada pakan ternak, maka seharusnya maggot menjadi daya tarik untuk menjalani kegiatan wirausaha yang membuka lapangan pekerjaan.

Menurut Azir et al. (2017), maggot merupakan salah satu pilihan sumber protein tinggi yang berasal dari hewani. Menurut Sugianto (2007) dalam jurnal Azir et al. (2017) menyatakan bahwa berdasarkan hasil penelitian, maggot yang dibudidayakan dengan menggunakan bungkil kelapa sawit yang telah difermentasi memiliki kandungan protein hingga 38,32\%. Kandungan yang dimiliki oleh maggot ini tentunya akan menjadikan pertumbuhan dari ternak yang diberikan pakan maggot ini nantinya pertumbuhannya akan lebih besar dibandingkan dengan ternak yang hanya diberikan pakan pabrik. Menurut 
Prosiding Seminar Nasional Pembangunan dan Pendidikan Vokasi Pertanian Politeknik Pembangunan Pertanian Manokwari, 14 November 2020

e ISSN : 2774-1982

Fahmi et al. (2009) Berikut analisis proksimat maggot besar (20-30 hari) dan maggot kecil (5-6 hari)

Tabel 2. Analisis Proksimat Maggot

\begin{tabular}{lll}
\hline Analisis Proksimat & Maggot Besar & Maggot Kecil \\
\hline Protein & $32.31 \%$ & $60.2 \%$ \\
\hline Lemak & $9.45 \%$ & $13.3 \%$ \\
\hline Abu & $4.86 \%$ & $7.7 \%$ \\
\hline Karbohidrat & $46.14 \%$ & $18.8 \%$ \\
\hline
\end{tabular}

Sumber: Jurnal Potensi Maggot Untuk Peningkatan Pertumbuhan Ikan, 2009.

Menurut Indarwaman (2014), maggot atau belatung selain memiliki protein tinggi, maggot juga mengandung anti jamur dan antimikroba sehingga jika dikonsumsi oleh ternak maka ternak tersebut akan memiliki antijamur dan anti mikroba dalam tubuhnya serta ternak juga memiliki daya tahan tubuh yang tinggi.

Analisis kelayakan usaha dibutuhkan untuk mengetahui apakah usaha tersebut layak untuk dijalankan atau tidak. Menurut Kasmir dan Jakfar (2012) terdapat lima tujuan perlu dilakukannya analisis kelayakan usaha sebelum usaha tersebut dijalankan, yaitu menghindari resiko kerugian, memudahkan perencanaan, mempermudah pelaksanaan pekerjaan, mempermudah pengawasan, mempermudah pengendalian. Menurut Kasmir dan Jakfar (2012) terdapat beberapa hal yang ingin dicapai dalam penilaian aspek teknis, yaitu perusahaan dapat menentukan lokasi yang tepat, baik untuk lokasi pabrik, gudang, cabang, maupun kantor pusat, perusahaan dapat menentukan layout yang sesuai dengan proses produksi yang dipilih, sehingga dapat memberikan efisiensi, perusahaan bisa menentukan teknologi yang paling tepat dalam menjalankan produksinya, perusahaan bisa menentukan metode persediaan yang paling baik untuk dijalankan sesuai dengan bidang usahanya, mampu menentukan kualitas tenaga kerja yang dibutuhkan sekarang dan di masa yang akan datang.

\section{METODE}

Setiap bisnis pasti membutuhkan investor untuk memngembangkan skala usaha yang sedang dijalankan, maka dari itu, di setiap bisnis perlu dilakukan sebuah analisis berupa analisis kelayakan bisnis melalui berbagai aspek secara menyeluruh agar mengetahui apakah bisnis tersebut dapat memberikan manfaat pada modal yang ditanamkan (Kusrina, 2011). Metode yang digunakan adalah metode kuantitatif dengan studi kelayakan dari aspek teknis produksi. Aspek teknis produksi terdiri dari proses 
Prosiding Seminar Nasional Pembangunan dan Pendidikan Vokasi Pertanian

Politeknik Pembangunan Pertanian Manokwari, 14 November 2020

e ISSN : 2774-1982

pembangunan bisnis secara teknis dan juga cara pengoperasiannya pasca bisnis tersebut selesai. Aspek teknis produksi dapat dikatakan layak apabila memenuhi syarat yaitu; lokasi produksi yang dekat dengan sumber bahan baku, luas produksi yang sudah optimal untuk mengelola bahan baku, layout atau penempatan alat penunjang produksi yang efisien, dan juga pemilihan teknologi yang tepat agar tidak menghambat jalannya proses produksi. Teknik yang digunakan untuk memperoleh data primer yaitu wawancara kepada pemilik usaha, pendapat para ahli yang diperoleh langsung dari sumbernya, dan hasil observasi langsung yang dilakukan peneliti. Sedangkan data sekunder adalah data yang berasal dari sumber lain yang relevan seperti jurnal ilmiah, buku, penelitian yang dilakukan sebelumnya dan data dari berbagai sumber (Sugiyono 2012).

\section{HASIL DAN PEMBAHASAN}

Aspek teknis yang dianalisis mencakup kegiatan pembudidayaan dan penanganan pascapanen, dan pengadaan kebutuhan produksi yang terdiri dari; kegiatan pemilahan sampah, pemberian pakan sampah organik dapur kepada maggot, pengelolaan dan pemeliharaan, permasalahan penyakit, panen dan pascapanen. Aspek teknis produksi ini dikatakan layak karena pemilihan lokasi produksi yang dekat dengan tempat penampungan sampah, di mana $60 \%$ dari sampah tersebut adalah sampah organik dapur. Selain dekat dengan tempat penampungan sampah, tenaga listrik dan air juga cukup tersedia untuk menunjang produksi yang dibutuhkan oleh kegiatan pembudidayaan. Tenaga kerja dan fasilitas transportasi juga memadai untuk menunjang produksi dan distribusi produk.

Pembudidayaan maggot BSF Dadali ini menggunakan lahan milik pribadi yang terletak di Kalibaru, Medan Satria, Bekasi, Jawa Barat yang tempat tersebut memang menjadi tempat penampungan sampah karena sebagian besar dari penduduknya bekerja sebagai pengepul barang bekas. Lahan yang digunakan adalah tempat pembuangan sampah sekaligus bank sampah milik Kang Mis yang tentunya sudah didesain sesuai dengan kebutuhan untuk membudidayakan maggot tersebut. Lahan tersebut memang sengaja dibangun oleh Kang Mis untuk menunjang kebutuhan produksi maggot, mulai dari penggilingan pakan, pemberian pakan, panen serta pascapanen. Luas lahan yang digunakan olehh Kang Mis ini berukuran 10 x 10 m yang dilengkapi dengan tempat pencacahan sampah, tempat budidaya maggot, tempat budidaya lalat bsf, dan tempat ternak unggas.

Komponen lain yang ikut andil dalam pembudidayaan maggot bsf adalah tenaga kerja atau karyawan. Tenaga kerja yang dipilih oleh pelaku usaha yaitu terdiri dari keluarga sendiri dan juga ada tenaga kerja di luar keluarga yaitu anak buah yang sebelumnya 
Prosiding Seminar Nasional Pembangunan dan Pendidikan Vokasi Pertanian Politeknik Pembangunan Pertanian Manokwari, 14 November 2020

e ISSN : 2774-1982

membantu pelaku usaha mengangkut sampah dari rumah-rumah warga dan juga memilahnya untuk dipisahkan khusus sampah organik dapur. Penggunaan tenaga kerja diluar keluarga juga ada yang membantu untuk mengurus dan memberikan makan maggot dengan sampah yang sudah dipilah sekaligus membersihkan kandang dan tempat pembudidayaan maggot. Berikut adalah beberapa gambar tempat produksi yang dijalankan oleh PPM BSF Dadali :

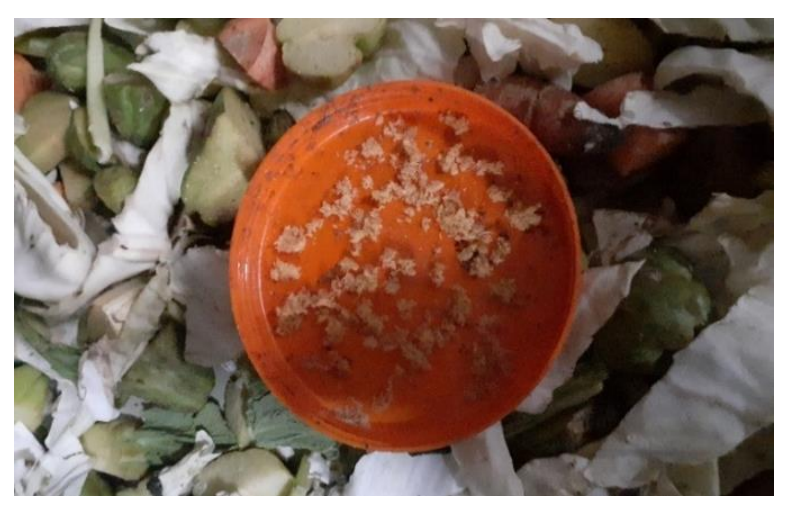

Gambar 1. Telur lalat bsf yang disimpan di krat berisi sampah organik dapur

Pada gambar di atas menunjukkan bahwa telur lalat bsf yang sudah dipisahkan dari induknya, disimpan dalam krat berisi sampah organik dapur sebanyak 2 kilogram yang nantinya akan menjadi makanan pertama dari telur maggot yang sudah menetas,

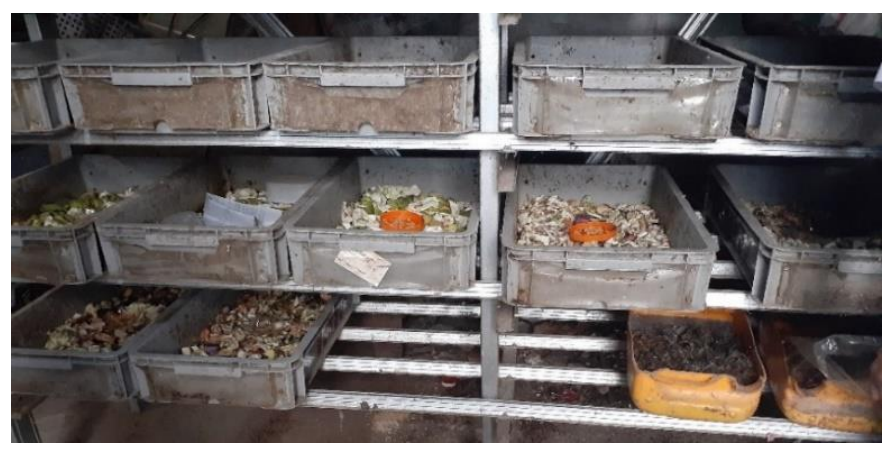

Gambar 2. Rak penyimpanan telur lalat bsf dalam krat

Pada gambar di atas menunjukkan tempat penyimpanan krat yang berisi telur lalat bsf yang nantinya akan menjadi maggot. Rak tersebut berisi banyak krat yang juga berisi telur yang sudah menetas menjadi maggot. Krat tersebut juga diisi dengan sampah organik dapur yang setiap harinya diisi sebanyak $2 \mathrm{~kg} / \mathrm{krat}$ yang nantinya akan menjadi makanan dari maggot tersebut. 


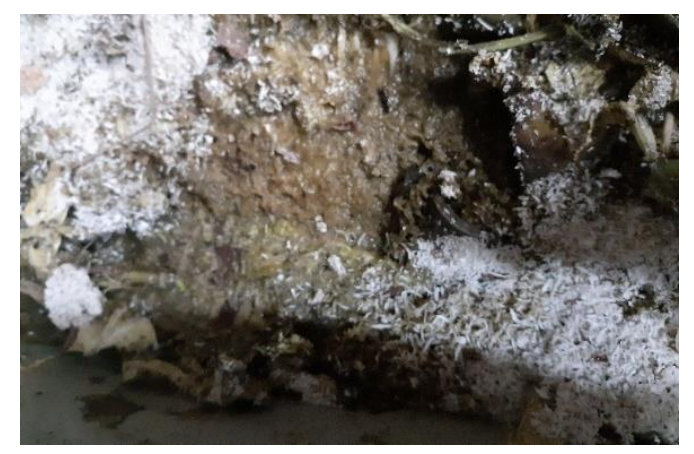

Gambar 3. Telur lalat bsf yang sudah menetas

Pada gambar di atas menunjukkan bahwa telur lalat bsf sudah menetas menjadi maggot. Bentuk dari maggot tersebut seperti ampas kelapa karena sangat kecil dan sangat halus pergerakannya tetapi maggot tersebut sudah mulai memakan sampah organik dapur yang berada dalam krat tempat penampungnya.

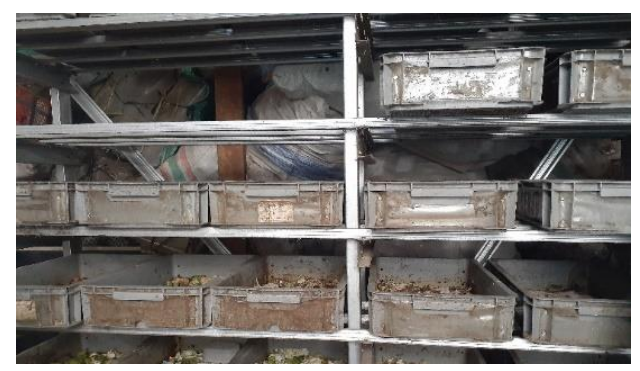

Gambar 4. Tempat penyimpanan maggot berusia 4 hari

Pada gambar di atas menunjukkan tempat penyimpanan maggot ketika maggot berusia 4 hari. Umumnya tempat penyimpanan yang digunakan oleh pelaku usaha adalah rak besi bertingkat yang dapat diisi oleh 5 krat setiap barisnya.

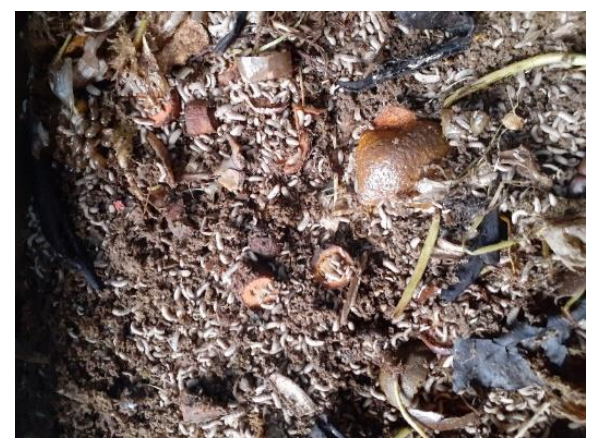

Gambar 5. Maggot berusia 4 hari

Pada gambar di atas menunjukkan maggot yang sudah berusia 4 hari. Pada gambar tersebut terlihat bahwa sampah yang setiap harinya dikonsumsi oleh maggot sudah menjadi kotoran maggot yang nantinya kotoran maggot tersebut dapat dijadikan kompos untuk diberikan pada tanaman. 
Prosiding Seminar Nasional Pembangunan dan Pendidikan Vokasi Pertanian Politeknik Pembangunan Pertanian Manokwari, 14 November 2020

e ISSN : 2774-1982

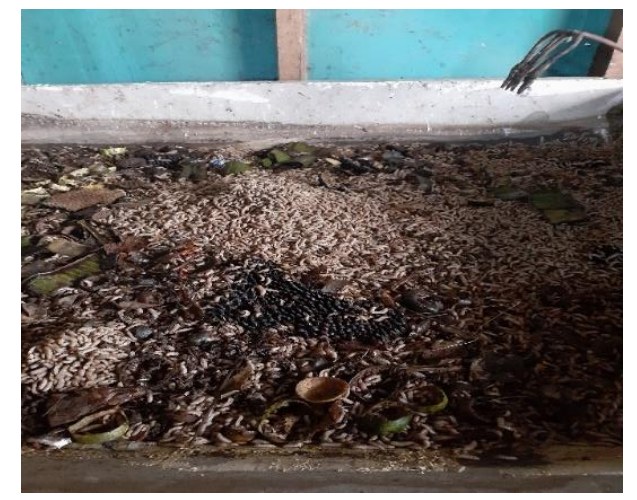

Gambar 6. Maggot berusia 13 hari

Pada gambar di atas menunjukkan bahwa maggot sudah berusia 13 hari, artinya maggot tersebut siap untuk dipindahkan karena nantinya maggot akan menjadi pre-pupa dan sebentar lagi akan menjadi lalat. Nantinya maggot yang siap menjadi pre-pupa akan memisahkan dirinya sendiri.

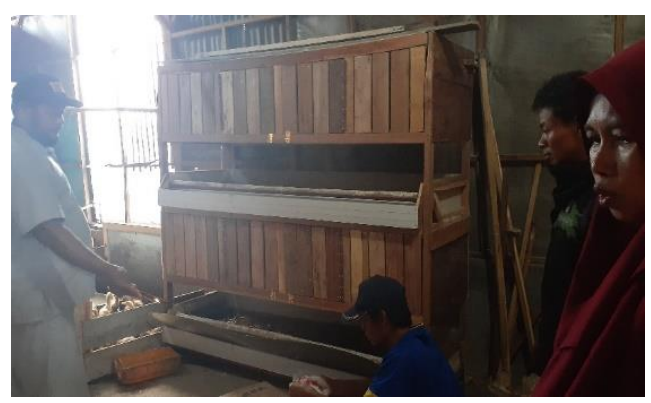

Gambar 7. Kandang maggot sekaligus kandang unggas

Pada gambar di atas menunjukkan kandang yang dibuat sendiri oleh pelaku usaha. Kandang tersebut dibuat sekaligus untuk kandang unggas yang nantinya akan menjadi usaha kedua dari pelaku budidaya maggot. Seperti pada gambar, kandang yang memiliki penutup vertikal adalah kandang yang nantinya akan menjadi kandang unggas dan di bawahnya menjadi kandang maggot yang berusia 10 hari keatas.

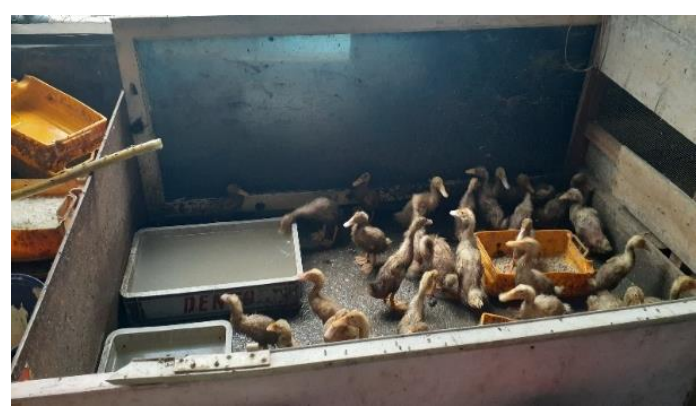

Gambar 8. Kandang bebek

Pada gambar di atas menunjukkan kandang bebek yang menjadi usaha lain dari pemilik usaha dan dijadikan uji coba penggunaan maggot sebagai pakan dari bebek 
Prosiding Seminar Nasional Pembangunan dan Pendidikan Vokasi Pertanian Politeknik Pembangunan Pertanian Manokwari, 14 November 2020

e ISSN : 2774-1982

tersebut. Hasil yang didapatkan dari campuran dedak, maggot dan juga sampah organik dapur menjadikan bebek dapat dijual hanya dalam rentang waktu 1 bulan. Terdapat juga sumber air ditandai dengan bak berisi air yang langsung diisi melalui selang dan kran air, dan juga adanya tenaga listrik untuk menyalakan lampu ketika di malam hari.

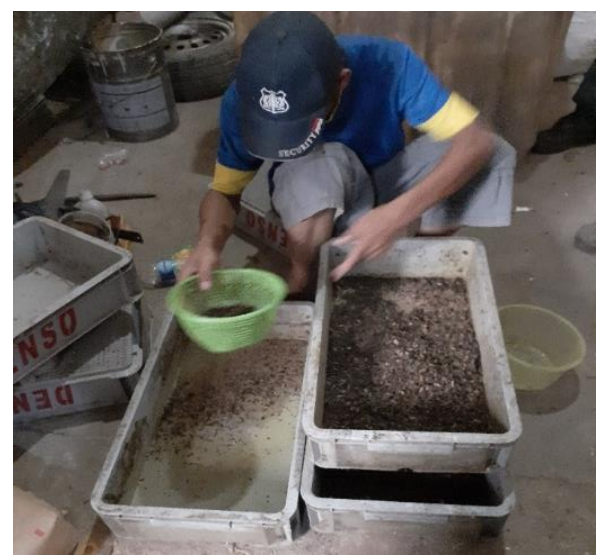

Gambar 9. Kegiatan pemisahan pre-pupa dengan kasgot

Pada gambar di atas menunjukkan bahwa maggot yang sudah menjadi pre-pupa dipisahkan dari kotorannya untuk nanti dipindahkan ke dalam kotak untuk disimpan di ruang gelap agar berevolusi menjadi lalat bsf kembali. Untuk saat ini pemisahan kasgot dengan pre-pupa masih dilakukan dengan cara manual dan dilakukan oleh karyawan produksi.

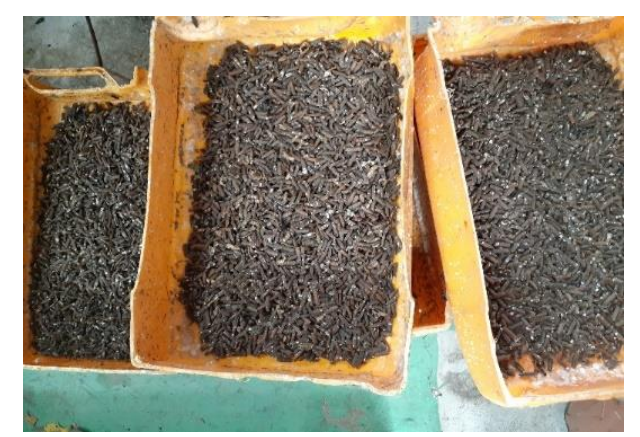

Gambar 10. Pre-pupa yang siap disimpan di ruang gelap

Pada gambar di atas menunjukkan bahwa pre-pupa yang sudah bersih dari kasgot disimpan di kotak, dan nantinya akan disimpan di ruang gelap dan nantinya akan menetas menjadi lalat bsf. Tempat penyimpanan ini harus menyatu dengan kandang lalat bsf agar pre-pupa yang sudah menjadi lalat dapat terbang keatas. 
Prosiding Seminar Nasional Pembangunan dan Pendidikan Vokasi Pertanian Politeknik Pembangunan Pertanian Manokwari, 14 November 2020

e ISSN : 2774-1982

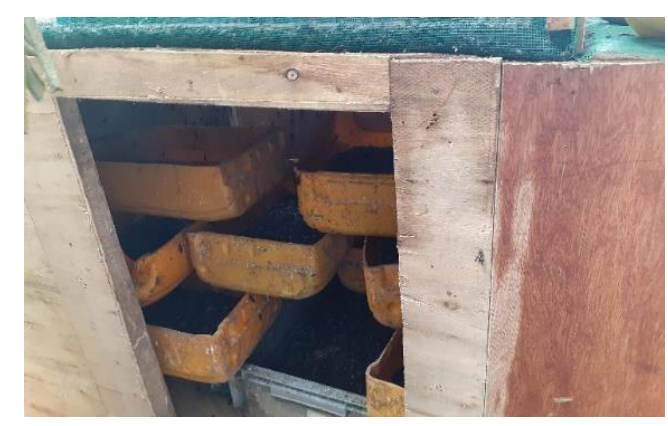

Gambar 11. Ruang gelap tempat penetasan pre-pupa menjadi lalat bsf

Pada gambar di atas menunjukkan ruang gelap yang dibuat oleh pelaku usaha. Ruang gelap tersebut harus ditutup rapat karena khawatir lalat bsf akan terbang keluar dari kandang yang disediakan. Selain menyimpan pre-pupa yang sudah siap, karyawan produksi juga harus mengambil kulit dari pre-pupa dan menggantinya pre-pupa yang baru. Ruang gelap tersebut ditutup dengan menggunakan kayu dan kayu tersebut dipaku agar tidak mudah lepas.

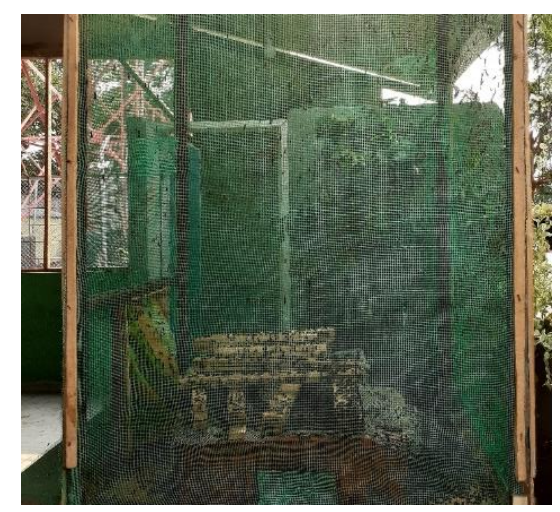

Gambar 12. Kandang lalat bsf

Pada gambar di atas menunjukkan kandang lalat bsf yang juga dibuat sendiri oleh pelaku usaha. Kandang lalat bsf ini ditutupi dengan jaring agar lalat tidak berterbangan keluar dari kandang. Kandang lalat bsf ini disimpan di luar ruangan agar lalat bsf dapat tumbuh secara baik. Hambatan dari disimpannya kandang di luar ruangan adalah banyak burung liar yang datang untuk memakan lalat dan membuat lubang pada jaring kandang tersebut. 


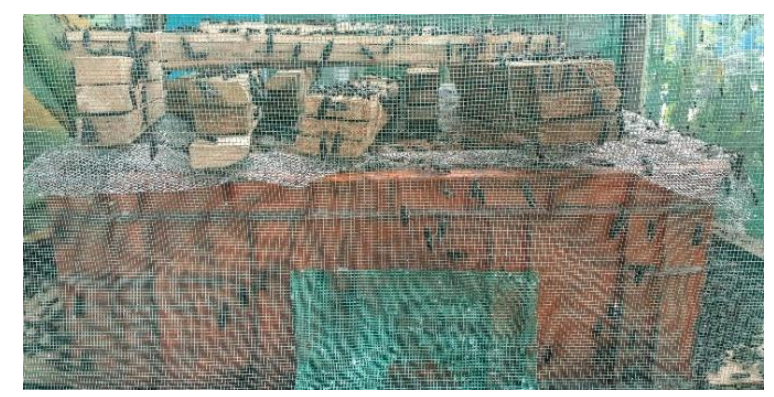

Gambar 13. Krat berisi air lindi

Pada gambar di atas menunjukkan krat yang berisi air lindi disimpan bersama dengan lalat-lalat yang beterbangan. Fungsi disimpannya krat yang berisi air lindi atau air dari sampah dan ditutupi dengan jaring tersebut adalah untuk menjadikan lalat bertelur hanya pada satu tempat. Kegiatan ini dilakukan atas pemikiran dan observasi oleh pelaku usaha sendiri agar lalat tersebut tidak bertelur di sembarang tempat dan juga memudahkan pelaku usaha untuk mengumpulkan telur yang nantinya akan disimpan pada krat seperti yang ada pada gambar 1 .

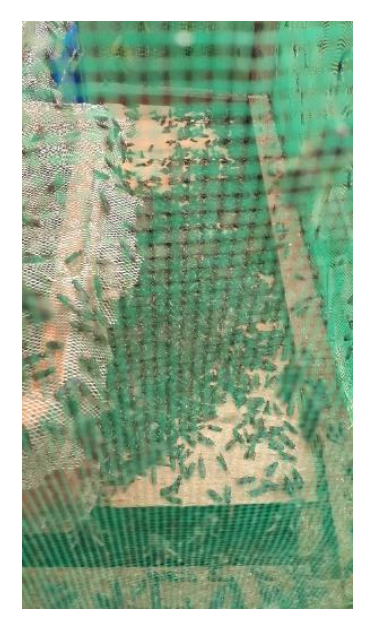

Gambar 14. Lalat yang sudah mati berjatuhan

Pada gambar di atas menunjukkan bahwa lalat-lalat yang sudah mati dikumpulkan dan diambil, nantinya lalat yang sudah mati ini akan dijadikan pakan unggas atau dijual untuk dijadikan pakan burung. Pada gambar di atas terlihat lubang yang berbentuk persegi panjang, di mana lubang tersebut adalah tempat keluarnya lalat dari ruang gelap yang berisi pre-pupa sebelumnya. 
Prosiding Seminar Nasional Pembangunan dan Pendidikan Vokasi Pertanian Politeknik Pembangunan Pertanian Manokwari, 14 November 2020

e ISSN : 2774-1982

\section{Proses Produksi Maggot BSF}
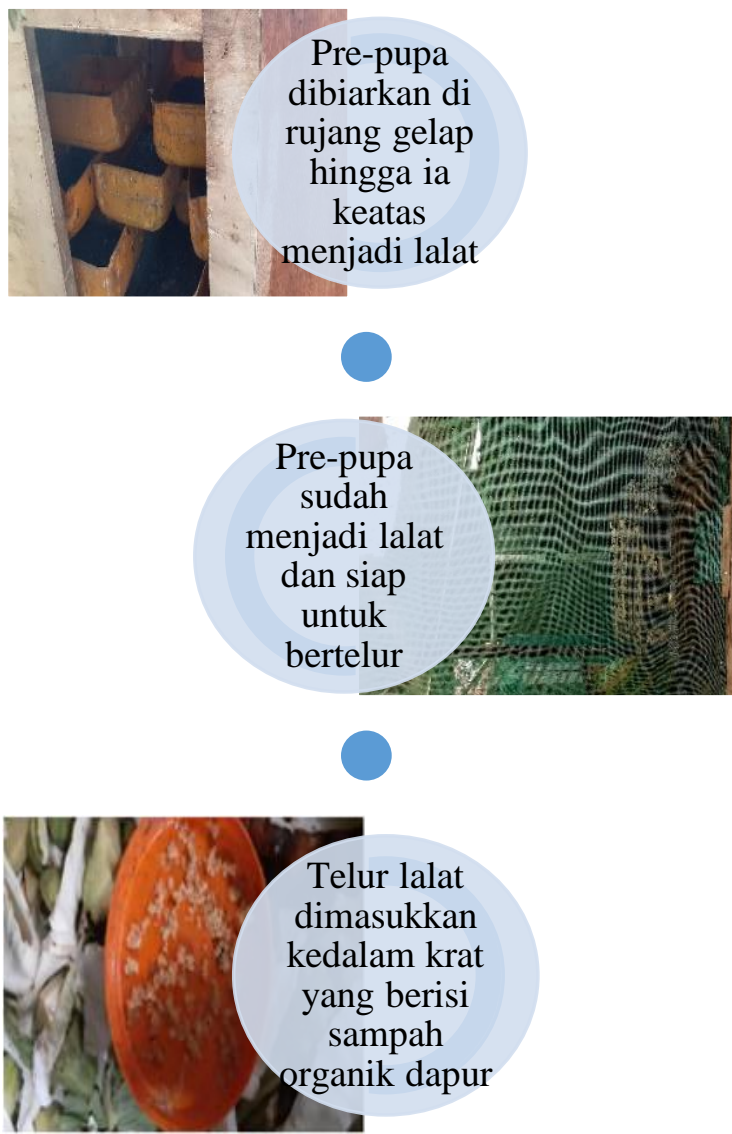

\section{Maggot} menetas dan siap untuk dipindah rak hingga berumur 18 hari

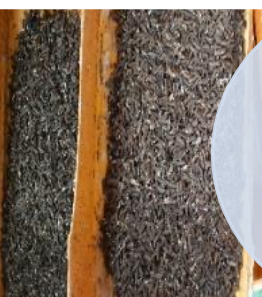

Maggot yang sudah berumur 18 hari dipindahkan ke ruang gelap yang nantinya akan menjadi lalat kembali 


\section{KESIMPULAN DAN SARAN}

Berdasarkan hasil analisis dan pembahasan penelitian ini, maka dapat diperoleh kesimpulan, hasil pengamatan analisis nonfinansial, pada aspek teknis produksi, usaha ini layak dijalankan karena lokasi yang dekat dengan sumber bahan baku, tersedia tenaga listrik dan juga air pada tempat produksi, dan juga tenaga kerja dan fasilitas yang sangat mendukung. Saran yang diberikan untuk pelaku usaha adalah perlu adanya peningkatan teknologi produksi dan juga peningkatan jumlah produksi karena pasar yang terbuka dan signifikannya perbedaan perkembangan ternak unggas yang menjadikan perputaran modal menjadi lebih cepat dan memberikan keuntungan yang juga cepat.

\section{DAFTAR PUSTAKA}

Azir A, et al. (2017). Produksi dan Kandungan Nutrisi Maggot (Chrysomya Megachepala) Menggunakan Komposisi Media Kultur Berbeda. Jurnal Ilmu-ilmu Perikanan dan Budidaya Perairan. 12(1): 35-36.

Azzahra, TA. (2020). Menteri LHK: Timbunan Sampah di Indonesia Tahun 2020 Capai 67.8 Juta Ton. [Internet]. [diunduh 2020 Agustus 3]. Tersedia pada: https://news.detik.com/berita/d-5046558/menteri-lhk-timbunan-sampah-diindonesia-tahun-2020-capai-678-juta-ton.

Baqiroh, NFAB. (2019). Timbulan Sampah Nasional Capai 64 juta ton per Tahun. [Internet]. [diakses 2020 November 4]. Tersedia pada: https://ekonomi.bisnis.com/read/20190221/99/891611/timbulan-sampahnasional-capai-64-juta-ton-per-tahun.

Ditjen Cipta Karya. (2019). Rekapitulasi Data Persampahan Provinsi. [Internet]. [diunduh 2020 Agustus 3]. Tersedia pada : http://ciptakarya.pu.go.id/plp/simpersampahan/baseline/rosampahdataprop list.php?id=3200\&tabid=dataumum.

Fahmi MR, et al. (2009). Potensi Maggot Untuk Peningkatan Pertumbuhan dan Status Kesehatan Ikan. Jurnal Ris. Akuakultur. 4(2): 221-232.

Indarmawan. (2014). Hewan Avertebrata Sebagai Pakan Ikan Lele. Purwokerto (ID): Fakultas Biologi Universitas Jenderal Soedirman.

Kasmir \& Jakfar. (2012). Studi Kelayakan Bisnis. Jakarta (ID): Prenada Media Group.

Kementrian Lingkungan Hidup dan Kehutanan. (2017). Komposisi Sampah di Indonesia Didominasi Sampah Organik. [Internet]. [diunduh 2020 Februari 2]. Tersedia pada: databoks.katadata.co.id/datapublish/2019/11/01/komposisi-sampah-di-indonesiadidominasi-sampah-organik.

Kementrian Lingkungan Hidup dan Kehutanan. (2018). Sistem Informasi Pengelolaan Sampah Nasional. [Internet]. [diunduh 2020 Juli 1]. Tersedia pada:http://sipsn.menlhk.go.id/?q=3atsph\&field_f_wilayah_tid=1427\&field_kat_ kota_tid=All\&field_periode_id_tid=2168. 
Prosiding Seminar Nasional Pembangunan dan Pendidikan Vokasi Pertanian

Politeknik Pembangunan Pertanian Manokwari, 14 November 2020

e ISSN : 2774-1982

Kusrina, R. (2011). Analisis Kelayakan Usaha Pengolahan Kerupuk Perusahan Kerupuk Cap Dua Gajah, Indramayu Jawa Barat. Skripsi Departemen Agribisnis Fakultas Ekonomindan Manajemen Institut Pertanian Bogor. Bogor.

Prasetyo, A. (2018). Rasio Wirausaha Indonesia Sentuh 7\%. Media Indonesia. [Internet]. [diakses 2020 November 4]. Tersedia pada: http://mediaindonesia.com/read/detail/164 639- rasio-wirausahaindonesia-sentuh-7.

Sugiyono. (2012). Memahami Penelitian Kualitatif. Bandung (ID): Alfabeta. 